\title{
Integrated management of plant-parasitic nematodes on guava and fig trees under tropical field conditions
}

\author{
Ahmed A. M. Dawabah ${ }^{*}$ (D), Fahad A. Al-Yahya ${ }^{2}$ and Hamzeh A. Lafi ${ }^{2}$
}

\begin{abstract}
Two field experiments were carried out to study the efficacy of different biological control agents in controlling certain plant-parasitic nematode species including Meloidogyne javanica, Tylenchorhynchus mediterraneus, Hoplolaimus seinhorsti, Longidorus latocephalus, and Xiphinema elongatum on guava and fig trees under the tropical field conditions of Jazan region, south-west Saudi Arabia during two successive seasons from Feb. 15, 2016 to Jan. 15, 2017. The evaluated bioagents were used in different integrated management combinations of certain fungal species (Trichoderma harzianum, Verticillium chlamydosporium, and Purpureocillium lilacinum), the bacterium Pasteuria penetrans, some organic amendments (cow manure, compost, and chicken manure), urea $46 \%$ as a nitrogenous fertilizer, and the nematicide carbofuran 10G for comparison. Results showed that all the tested treatments gradually decreased $(P \leq 0.05)$ the population densities of plant-parasitic nematodes on guava and fig trees over the study period. The highest reduction of nematode densities occurred at the end of the experiment. Carbofuran 10G was the most effective treatment in suppressing the nematode densities on guava and fig trees. The most effective management combinations, next to carbofuran 10G, in suppressing the nematode densities in the rhizosphere of guava trees were $P$. lilacinum $+P$. penetrans + urea $46 \%$, $P$. lilacinum $+P$. penetrans + chicken manure, and T. harzianum + P. penetrans + chicken manure (66.54-69.22\% nematode reductions). Correspondent combinations in the rhizosphere of fig trees were $P$. lilacinum $+P$. penetrans + cow manure, $T$. harzianum + P. penetrans + cow manure, $P$. lilacinum + P. penetrans + urea 46\%, and V. chlamydosporium + P. penetrans + urea 46\% (54.68-57.17\% nematode reductions). On the other hand, nematode population densities continued to increase $(P \leq 0.05)$ in the rhizosphere of guava and fig trees in the absence of nematode management combinations. All the tested treatments significantly increased $(P \leq 0.05)$ the number of fruits/tree on guava and fig trees. Treatments which included the combinations of fungal and bacterial parasites along with chicken manure gave the highest numbers of fruits/tree, followed by the treatment with the nematicide carbofuran 10G. Regression analysis showed a significant negative linear relationship between the number of nematodes/kg soil and the number of guava and fig fruits/tree.
\end{abstract}

Keywords: Plant-parasitic nematodes, Integrated management, Ficus carica, Psidium guajava, Saudi Arabia

\section{Background}

Jazan region, southwest corner of Saudi Arabia, is noted for its high-quality production of some tropical and subtropical fruits including mango, fig, guava, banana, papaya, and avocado (Basha 1998). In the past two decades, the root-knot nematodes, Meloidogyne spp. Göldi, have been reported on some species of the tropical fruit trees grown

\footnotetext{
* Correspondence: dawabah@hotmail.com

${ }^{1}$ Nematode Diseases Research Department, Plant Pathology Research Institute, Agricultural Research Center, 9 Gameat El-Qahera street, Giza 12619, Egypt

Full list of author information is available at the end of the article
}

in the region, especially guava, Psidium guajava L. and fig, Ficus carica L. (Mokbel 2014). Gomes et al. (2008) showed that guava trees infected, with Meloidogyne mayaguensis Rammah \& Hirschmann, suffered from the deficiency of nitrogen, potassium, phosphorus, calcium, and magnesium, and these mineral deficiencies were proportionally related to the severity of root galling and root decay, which ultimately led to the death of guava trees within a few months. Unlike, the persistence of chemical nematicides is usually short in the tropics, due to run-off and leaching. Besides, many of the effective nematicides were banned from the markets owing to their risks to human 
health and environment. So, alternative control measures should be adopted to replace those compounds. The concept of combining compatible tactics for controlling nematodes predates that of integrated pest management (IPM) (Barker 2013).

The biological control agents of nematodes include many microorganisms, but the most important are fungi and bacteria. Purpureocillium lilacinum (Thom) Luangsa-ard, Houbraken, Hywel-Jones \& Samson, Trichoderma harzianum Rifai, and Verticillium clamydosporium Goddard were announced to be the most potent fungal parasites that can effectively control Meloidogyne spp. on many host plants (Rao 2007). Pasteuria penetrans Sayre \& Starr, a mycelial endospore-forming bacterial parasite, represents another successful bio-control agent against root-knot nematodes (Chen et al. 1996). P. lilacinum offers a successful biological control against many pathogenic nematode species (Jatala 1986). For example, it effectively controlled Tylenchulus semipenetrans Cobb on mandarin and rough lemon, and the results were best when the fungus was combined with oil-cakes (Le Roux et al. 2000). Also, when P. lilacinum and the bacteria Pseudomonas fluorescens Migula were combined to enrich the farm yard manure, which was added to the rhizosphere of papaya seedlings, the root populations of Rotylenchulus reniformis Linford \& Oliveira and Meloidogyne incognita (Kofoid \& White) Chitwood were reduced by $73 \%$ and $78 \%$, respectively, and the papaya yield was increased by $26 \%$ (Rao 2010). As well, T. harzianum effectively suppressed the population of the root-knot nematode, M. enterolobii Yang \& Eisenback in both soil and roots of guava in Thailand (Jindapunnapat et al. 2013). When the nursery soil of papaya trees was treated by $T$. harzianum and the rhizobacteria $P$. fluorescens, either in a single or combined applications, $M$. incognita was greatly controlled and the papaya yield was increased (Rao 2007). De Leij et al. (1992) reported the potential of some Verticillium chlamydosprium isolates against $M$. arenaria on tomato plants. In Saudi Arabia, Al-Hazmi et al. (2013) found a heavy colonization of the cysts of Heterodera avenae Woll. with the fungus Verticillium chlamydosporium. The bacterium $P$. penetrans has shown a great control potential against many plant-parasitic nematode species, especially Meloidogyne spp. (Chen and Dickson 1998). This bacterial parasite has been reported adhering to, or infesting hundreds of nematode species from many countries worldwide (Sturhan 1988). Al-Rehiayani (2007) reported the potential of $P$. penetrans in controlling M. incognita on grape in Al-Qasim region, Saudi Arabia.

Organic and inorganic nitrogenous amendments, which have been usually added to soil to improve soil fertility, have also offered good nematicidal effects against plantparasitic nematodes (Oka 2010). Urea and ammonia were found to be effective in controlling the plant-parasitic nematodes at rates as low as $300-400 \mathrm{mg} / \mathrm{kg}$ soil (Rodriguez-
Kabana 1986). Guava decline disease, a complex disease involving M. mayaguensis and Fusarium solani Keratitis, has been greatly managed in a commercial guava plantation and a major yield gains were obtained by the applications of cow manure and poultry compost (Gomes et al. 2010).

This study aimed to evaluate different bio-control agents in an integrated management combinations to manage the nematode problems on guava and fig trees under the tropical field conditions of Jazan region, southwest of Saudi Arabia.

\section{Materials and methods}

Two field experiments were carried out in a 2-year-old guava and fig orchards located at Abu Areesh governorate, Jazan region, southwest of Saudi Arabia to study the efficacy of different integrated combinations of biological control agents in controlling certain plant-parasitic nematode (PPN) species.

\section{Nematode infestation and identification}

Soil of guava and fig orchards were naturally infested with a group of plant-parasitic nematode (PPN) species including Meloidogyne javanica (Treub) Chitwood, Tylenchorhynchus mediterraneus Handoo, Hoplolaimus seinhorsti Luc, Longidorus latocephalus Lamberti, Choleva and Agostinelli, and Xiphinema elongatum Schuurmans Stekhoven \& Teunissen. These nematode species were morphologically and molecularly characterized by Dawabah and Al-Yahya (2017), and their frequency of occurrence (FO \%) in both guava and fig orchards at the beginning of the experiments were determined (Table 1). The experiments were carried out during two successive seasons from Feb. 15, 2016 to Jan. 15, 2017. Guava and fig trees were spaced $(5 \times 5 \mathrm{~m})$, and irrigated by sprinklers as needed.

One week prior to the implementation of the two experiments on guava and fig trees (8th of Feb., 2016), rhizosphere soil samples were collected from under the trees of the two orchards, representing the experimental units for the different treatments, to extract and count the initial population densities ( $\mathrm{Pi}$ ) of PPN species in each

Table 1 Frequency of occurrence (FO\%) of plant-parasitic nematodes associated with guava, Psidium guajava and fig, Ficus carica, at the beginning of the management experiments

\begin{tabular}{lll}
\hline Genus/species & \multicolumn{2}{l}{ Frequency of occurrence (FO\%) } \\
\cline { 2 - 3 } & Guava & Fig \\
\hline Hoplolaimus seinhorsti & 24.1 & 13.0 \\
Longidorus latocephalus & 13.0 & 16.7 \\
Meloidogyne javanica & 57.4 & 53.7 \\
Tylenchorhynchus mediterraneus & 46.3 & 41.5 \\
Xiphinema elongatum & 5.0 & 8.9 \\
\hline
\end{tabular}

Frequency of occurrence $(\mathrm{FO} \%)=$ (number of samples containing a species / number of collected samples) $\times 100$ 
experimental unit (tree). Accordingly, trees with approximately close numbers of PPNs were selected, labeled, and assigned randomly at four replicates (trees)/treatment, in a complete randomized design (CRD) (Siddiqi et al. 2007). Beside, a map was designed for each experiment.

\section{Identification and preparation of fungal and bacterial inocula}

$T$. harzianum and V. chlamydosporium were isolated from the egg masses of the root-knot nematode, M. javanica, collected from galled guava roots grown in Riyadh region, central Saudi Arabia. Egg masses were surface sterilized by $0.1 \% \mathrm{NaOCl}$ for $30 \mathrm{~s}$, washed three times in a sterile distilled water, and then transferred to Petri dishes containing sterilized potato dextrose agar (PDA). Petri dishes were incubated at $25{ }^{\circ} \mathrm{C}$ and observed for fungal growth. Pure isolates of $T$. harzianum and $V$. chlamydosporium, isolated and identified, based on the cultural and spore morphological features, were also sent to the Plant Pathology Research Institute, Agricultural Research Center, Giza, Egypt to confirm the identification. An aggressive German isolate of P. lilacinum (DSMZ 14052) was obtained from Damascus University. The fungi: T. harzianum, V. chlamydosporium, and P. lilacinum were continuously maintained on PDA for further use.

To prepare fungal inocula, wheat grains were immersed in water over night, and weights of $250 \mathrm{~g}$ of wetted grains were transferred to $500 \mathrm{ml}$ conical flasks, which were autoclaved at 15 psi for 20 min twice. Each flask containing sterilized wheat grains was inoculated by a couple of 2-mm discs of the designated fungus and incubated at $25^{\circ}$ $\mathrm{C}$ for 2 weeks. The flasks were shaken every 3-4 days to ensure the uniform colonization of the fungus. For fungal infestation in the field soil, the basin of each tree was infested with $1 \mathrm{~kg}$ of fungal-infected wheat grains, distributed in the top $20 \mathrm{~cm}$ soil of the tree basin.

A local isolate of the endospore forming bacteria, $P$. penetrans, was isolated from $M$. javanica second-stage juveniles $\left(\mathrm{J}_{2}\right)$, parasitizing olive roots at Al-Melaidah, Al-Qasim, Saudi Arabia. This local bacterial isolate was previously identified on a molecular basis by Al-Rehiayani and Motawei (2014). M. javanica $\mathrm{J}_{2} \mathrm{~s}$, with bacterial endospores attached, were obtained by centrifugation (Hewlett and Dickson 1993), and used to inoculate susceptible tomato plants cv. "Sulatana-7," growing in a steam-sterilized sandy loam soil at $3000 \mathrm{~J}_{2} \mathrm{~s} /$ plant/pot. Tomato plants were harvested, 60 days after inoculation, uprooted and the root systems were washed, then air dried on a lab. bench. Aliquots of root materials $(0.5 \mathrm{~g} / 5 \mathrm{ml}$ water $)$ were homogenized, using a pestle and a mortar. Homogenates were then passed through a 35 mesh (50 $\mu$ openings) sieve (Bird and Brisbane 1988). Number of released endospores in the suspension was determined, using a hemocytometer, and adjusted to a concentration of $1 \times 10^{7} / \mathrm{ml}$. The bacterial inoculum consisted of $20 \mathrm{ml}$ of the bacterial endospore suspension/tree basin (Abd-Elgawad et al. 2010).

\section{The nematicidal and organic amendments}

Cow manure (organic matter $=50 \%, \mathrm{pH}=7.5$, humidity $=$ $20-25 \%, \mathrm{C} / \mathrm{N}$ ratio $=25: 1$ ) and compost (organic matter $=$ $52 \%, \mathrm{pH}=7.0$, humidity $=20 \%, \mathrm{C} / \mathrm{N}$ ratio $=30: 1$ ) were used at $300 \mathrm{~kg} / \mathrm{ha}$ (1 kg/tree) (Siddiqi et al. 2007), while chicken manure (organic matter $=82.35 \%, \mathrm{pH}=7.0$, humidity $=21.6 \%, \mathrm{C} / \mathrm{N}$ ratio $=20: 1)$ and urea (46\% nitrogen) were added at $50 \mathrm{~g} /$ tree. All organic materials were obtained from the local market, as pure sterilized dry powders. For comparison, the nematicide, carbofuran 10G was used at $40 \mathrm{~g} /$ tree. All the tested materials were incorporated uniformly in the top $20 \mathrm{~cm}$ soil of the tree basin.

\section{Application of treatments}

The first application of the treatments took place on the 15th of Feb., 2016. Three months later (on the 15th of May, 2016), root and rhizosphere soil samples were collected from the trees of both experiments to determine the numbers of nematodes/tree, and the mean number of nematodes/treatment. The treatments (T1-T14) included:

- T 1: P. lilacinum + P. penetrans + chicken manure.

- T 2: V. chlamydosporium + P. penetrans + chicken manure.

- T 3: T. harzianum + P. penetrans + chicken manure.

- T 4: P. lilacinum + P. penetrans + cow manure.

- T 5: V. chlamydosporium + P. penetrans + cow manure.

- T 6: T. harzianum + P. penetrans + cow manure.

- T 7: P. lilacinum + P. penetrans + urea $46 \%$.

- T 8: V. chlamydosporium + P. penetrans + urea 46\%.

- T 9: T. harzianum + P. penetrans + urea $46 \%$.

- T 10: P. lilacinum + P. penetrans + compost.

- T 11: V. chlamydosporium $+P$. penetrans + compost.

- T 12: T. harzianum + P. penetrans + compost.

- T 13. Carbofuran $10 \mathrm{G}$

- T 14: Non-treated trees (check).

The second application of the treatments (same as in the first one) took place on the 15th of Oct., 2016, and also number of nematodes per each tree was determined. Three months later (on the 15th of Jan., 2017), rhizosphere soil samples were collected from all the experimental units (trees) and the mean number of nematodes/treatment (final nematode populations $=\mathrm{Pf}$ ) was determined in both experiments.

\section{Data analysis}

Data were statistically analyzed, using SPSS (2016), and means were separated using Fisher's Protected $\mathrm{LSD}_{0.05}$. 


\section{Results and discussion}

All the tested treatments significantly reduced $(P \leq 0.05)$ the population densities of PPN in the rhizosphere of guava and fig trees in the two separate field experiments (Tables 2 and 3). Nematode populations ( $M$. javanica, T. mediterraneus, H. seinhorsti, L. latocephalus, and X. elongatum) gradually decreased at all the tested treatments over the study period from Feb. 15, 2016 to Jan. 15, 2017. The highest reductions were achieved by the end of the experiments (final nematode populations) (Tables 2 and 3). In both experiments, carbofuran 10G was the most effective treatment in suppressing the nematode population densities in the rhizosphere of guava and fig trees (80.13 and 83.13\%, respectively). Actually, chemical treatments mostly have the advantage of the quick and effective response in controlling plant-parasitic nematodes. Soltani et al. (2013) found that aldicarb, enzone, oxamyl, and cadusafos at 6 and $8 \mathrm{ppm}$ concentrations were effective treatments in controlling the root-knot nematode, $M$. javanica, on 1-year old olive seedlings in the greenhouse.

Next to carbofuran treatment, the most effective combinations of the tested treatments in suppressing the nematode population densities in the rhizosphere of guava trees were $P$. lilacinum $+P$. penetrans + urea $46 \%$, $P$. lilacinum
$+P$. penetrans + chicken manure, and $T$. harzianum $+P$. penetrans + chicken manure (66.54-69.22\% nematode reductions), followed by $T$. harzianum $+P$. penetrans + chicken manure, $V$. chlamydosporium $+P$. penetrans + urea 46\%, and T. harzianum + P. penetrans + urea 46\% (55.52$59.38 \%$ nematode reductions) (Table 2). Correspondent combinations in the rhizosphere of fig trees were $P$. lilaci$n u m+P$. penetrans + cow manure, $T$. harzianum $+P$. penetrans + cow manure, $P$. lilacinum $+P$. penetrans + urea $46 \%$, and $V$. chlamydosporium $+P$. penetrans + urea 46\% (54.68-57.17\% nematode reductions), followed by $V$. chlamydosporium $+P$. penetrans + compost and P. lilaci$n u m+P$. penetrans + chicken manure $(39.27-49 \%$ nematode reductions) (Table 3).

On the other hand, nematode population densities gradually increased $(P \leq 0.05)$ in the rhizosphere of guava and fig trees in the absence of nematode-control measures (non-treated control). These increments reached up to 75.3 and $35.46 \%$ in the rhizosphere of guava and fig trees, respectively, by the end of the experiments (Tables 2 and 3).

The ability of the different non-chemical combinations used in this study is greatly consistent with the results of previous studies. Many alternative control measures have been recently adopted to replace the chemical

Table 2 Effect of different combinations of integrated control measures on the number of plant-parasitic nematodes (PPN) associated with guava, Psidium guajava, rhizosphere

\begin{tabular}{|c|c|c|c|c|c|}
\hline \multirow[t]{2}{*}{ Treatment } & \multicolumn{4}{|c|}{ Number of PPN/200 $\mathrm{cm}^{3}$ soil } & \multirow{2}{*}{$\begin{array}{l}\% \text { final } \\
\text { Change }\end{array}$} \\
\hline & $15 / 2 / 2016^{a}$ & $15 / 5 / 2016$ & $15 / 10 / 2016^{b}$ & $15 / 1 / 2017$ & \\
\hline$P$. lilacinum + P. penetrans + chicken manure & $652.50 \mathrm{a}$ & $492.50 \mathrm{~b}$ & 348.75 c & $202.50 \mathrm{~d}$ & -68.97 \\
\hline$V$. chlamydosporium $+P$. penetrans + chicken manure & $640.00 \mathrm{a}$ & $556.25 \mathrm{ab}$ & $486.25 b$ & $260.00 \mathrm{C}$ & -59.38 \\
\hline T. harzianum +P. penetrans + chicken manure & $650.00 \mathrm{a}$ & $511.25 b$ & $450.00 \mathrm{~b}$ & $217.50 \mathrm{c}$ & -66.54 \\
\hline$P$. lilacinum $+P$. penetrans + cow manure & $717.50 \mathrm{a}$ & $662.50 \mathrm{a}$ & $537.50 \mathrm{~b}$ & $380.00 \mathrm{C}$ & -47.04 \\
\hline$V$. chlamydosporium $+P$. penetrans + cow manure & $851.25 \mathrm{a}$ & $772.50 \mathrm{a}$ & 793.75 a & $488.75 b$ & -36.73 \\
\hline T. harzianum $+P$. penetrans + cow manure & $757.50 \mathrm{a}$ & $736.25 \mathrm{ab}$ & $651.25 b$ & $433.75 \mathrm{c}$ & -42.74 \\
\hline$P$. lilacinum $+P$. penetrans + compost & $732.50 \mathrm{a}$ & $562.50 \mathrm{~b}$ & $484.00 \mathrm{~b}$ & 396.25 c & -45.90 \\
\hline$V$. chlamydosporium $+P$. penetrans + compost & $741.25 \mathrm{a}$ & $788.75 \mathrm{a}$ & $590.00 \mathrm{~b}$ & $567.50 \mathrm{~b}$ & -23.44 \\
\hline T. harzianum + P. penetrans + compost & $715.00 \mathrm{a}$ & $651.25 \mathrm{ab}$ & $581.50 \mathrm{bc}$ & $536.25 c$ & -17.66 \\
\hline P. lilacinum + P. penetrans + urea 46\% & $683.75 \mathrm{a}$ & 608.75 a & $512.50 \mathrm{~b}$ & $210.00 \mathrm{c}$ & -69.29 \\
\hline V. chlamydosporium + P. penetrans + urea $46 \%$ & $736.25 \mathrm{a}$ & $633.75 b$ & $553.75 b$ & $327.50 \mathrm{c}$ & -55.52 \\
\hline T. harzianum + P. penetrans + urea $46 \%$ & $755.00 \mathrm{a}$ & $661.25 b$ & $642.50 \mathrm{~b}$ & $328.75 \mathrm{C}$ & -56.46 \\
\hline Carbofuran10G & $773.75 \mathrm{a}$ & $327.50 \mathrm{~b}$ & $175.00 \mathrm{C}$ & $153.75 \mathrm{c}$ & -80.13 \\
\hline Nematode control & $738.75 \mathrm{~d}$ & $993.75 \mathrm{C}$ & $1170.00 \mathrm{~b}$ & $1295.00 \mathrm{a}$ & +75.30 \\
\hline $\mathrm{LSD}_{0.05}$ between treatments & 85.62 & & & & \\
\hline LSD $_{0.05}$ between times & 46.98 & & & & \\
\hline $\mathrm{LSD}_{0.05}$ between treatments $\times$ times & 175.77 & & & & \\
\hline
\end{tabular}

Data are average of four replicates (trees) each

Values followed by the same letter(s) in a row are not significantly different at $P \leq 0.05$

$P$. lilacinum $=$ Purpureocillium lilacinum,$P$. penetrans $=$ Pasteuria penetrans, $V$. chlamydosporium $=$ Verticillium chlamydosporium, $T$. harzianum $=$

Trichoderma harzianum

${ }^{\text {a }}$ First treatments application

${ }^{b}$ Second treatments application (beginning of the second season)

${ }^{c}$ Compared to the number of PPN at the beginning of the experiment (Pi) 
Table 3 Effect of different combinations of integrated control measures on the number of plant-parasitic nematodes (PPN) associated with fig, Ficus carica, rhizosphere

\begin{tabular}{|c|c|c|c|c|c|}
\hline \multirow[t]{2}{*}{ Treatment } & \multicolumn{4}{|c|}{ Number of PPN/200 $\mathrm{cm}^{3}$ soil } & \multirow{2}{*}{$\begin{array}{l}\% \text { final } \\
\text { Change }^{c}\end{array}$} \\
\hline & $15 / 2 / 2016^{a}$ & $15 / 5 / 2016$ & $15 / 10 / 2016^{b}$ & $15 / 1 / 2017$ & \\
\hline P. lilacinum + P. penetrans + chicken manure & $547.50 \mathrm{a}$ & $483.75 \mathrm{ab}$ & $457.50 \mathrm{~b}$ & $332.50 \mathrm{c}$ & -39.27 \\
\hline V. chlamydosporium + P. penetrans + chicken manure & $507.50 \mathrm{a}$ & $400.00 \mathrm{~b}$ & $440.00 \mathrm{ab}$ & 393.75 b & -22.41 \\
\hline T. harzianum $+P$. penetrans + chicken manure & $557.50 \mathrm{a}$ & $532.50 \mathrm{ab}$ & $472.50 \mathrm{bc}$ & $383.75 \mathrm{C}$ & -31.17 \\
\hline$P$. lilacinum $+P$. penetrans + cow manure & $641.25 \mathrm{a}$ & $612.50 \mathrm{a}$ & $327.50 \mathrm{~b}$ & $288.75 b$ & -54.97 \\
\hline$V$. chlamydosporium $+P$. penetrans + cow manure & $535.00 \mathrm{a}$ & $448.75 \mathrm{C}$ & $545.00 \mathrm{~b}$ & $403.75 \mathrm{C}$ & -24.53 \\
\hline T. harzianum $+P$. penetrans + cow manure & 516.25 a & 438.75 b & $292.50 \mathrm{C}$ & $223.75 c$ & -56.66 \\
\hline P. lilacinum $+P$. penetrans + compost & $632.50 \mathrm{a}$ & $553.75 \mathrm{ab}$ & $498.75 b$ & $387.50 \mathrm{c}$ & -38.74 \\
\hline$V$. chlamydosporium $+P$. penetrans + compost & $625.00 \mathrm{a}$ & $615.00 \mathrm{a}$ & $522.50 \mathrm{~b}$ & 318.75 C & -49.00 \\
\hline T. harzianum + P. penetrans + compost & 536.25 a & $422.50 \mathrm{~b}$ & $405.00 \mathrm{~b}$ & $302.50 \mathrm{c}$ & -43.59 \\
\hline P. lilacinum + P. penetrans + urea $46 \%$ & $575.00 \mathrm{a}$ & $377.50 \mathrm{~b}$ & $330.00 \mathrm{bc}$ & $246.25 c$ & -57.17 \\
\hline V. chlamydosporium + P. penetrans + urea $46 \%$ & $695.00 \mathrm{a}$ & $531.25 \mathrm{~b}$ & $497.50 \mathrm{~b}$ & $315.00 \mathrm{c}$ & -54.68 \\
\hline T. harzianum + P. penetrans + urea $46 \%$ & 568.75 a & $458.75 \mathrm{~b}$ & $420.00 \mathrm{bc}$ & $360.00 \mathrm{c}$ & -36.70 \\
\hline Carbofuran10G & $622.50 \mathrm{a}$ & $115.00 \mathrm{~b}$ & $160.00 \mathrm{~b}$ & $105.00 \mathrm{~b}$ & -83.13 \\
\hline Nematode control & 606.25 c & $712.50 \mathrm{~b}$ & $781.25 \mathrm{ab}$ & $821.25 \mathrm{a}$ & +35.46 \\
\hline $\mathrm{LSD}_{0.05}$ between treatments & 89.13 & & & & \\
\hline LSD $_{0.05}$ between times & 47.64 & & & & \\
\hline $\mathrm{LSD}_{0.05}$ between treatments $\times$ times & 178.27 & & & & \\
\hline
\end{tabular}

Data are average of four replicates (trees) each

Values followed by the same letter(s) in a row are not significantly different at $P \leq 0.05$

$P$. lilacinum $=$ Purpureocillium lilacinum,$P$. penetrans $=$ Pasteuria penetrans, $V$. chlamydosporium $=$ Verticillium chlamydosporium, $T$. harzianum $=$

Trichoderma harzianum

${ }^{\mathrm{a}}$ First treatments application

${ }^{\mathrm{b}}$ Second treatments application (beginning of the second season)

${ }^{c}$ Compared to the number of PPN at the beginning of the experiment (Pi)

compounds due to their hazardous effects (Sahebani and Hadavi 2008; Jindapunnapat et al. 2013). P. lilacinum, T. harzianum, and $V$. clamydosporium, as fungal parasites of nematode eggs and adults (Rao 2007) as well as $P$. penetrans as a bacterial parasite (Chen et al. 1996) were previously reported among the most potent measures used in this subject. In addition, urea and nitrogenous fertilizers are considered to be good nematicides when applied at levels as low as $300-400 \mathrm{mg} / \mathrm{kg}$ soil (Rodriguez-Kabana 1986; Alam 1992; Al-Hazmi and Dawabah 2014; Al-Hazmi et al. 2017). Likewise, many previous studies have shown that organic and inorganic nitrogen amendments had a nematicidal effect against plant-parasitic nematodes (Rodriguez-Kabana 1986; Akhtar and Malik 2000; Oka 2010).

As shown, in the present study, reductions of the nematode densities in the rhizosphere of guava and fig trees were much higher when chicken manures, cow manure, and urea $46 \%$ were added along with the fungal and bacterial parasites. These findings are in agreement with the results of previous studies which used the fungus $P$. lilacinum and the bacteria $P$. fluorescens to enrich the farm yard manure, then applied the enriched manure to the rhizosphere of papaya seedlings to effectively control the reniform nematode, $R$. reniformis, and the root-knot nematode, M. incognita (Rao 2007 and 2010). Similarly, the fungus $P$. lilacinum was previously found suppressing the population densities of the citrus nematode, T. semipenetrans, on citrus seedlings in pot experiments, and the results were best when the fungus was combined with organic amendments (oil-cakes) (Le Roux et al. 2000). Gomes et al. (2010) concluded also that coupling the control treatments with organic soil amendments, particularly poultry compost and cow manure spread evenly under the guava canopy, gave a better control of the root-knot nematode, M. mayaguensis. In fact, organic soil amendments stimulate the activities of soil microorganisms that are antagonistic to plant-parasitic nematodes. The decomposition of organic matter results in the accumulation of specific compounds in the soil that may have nematicidal effects against nematodes (Akhtar and Malik 2000). In addition, long-term effects might include increases in the population densities of the nematode antagonists in the soil. Also, improved crop nutrition and plant 
growth following amendments use might lead to tolerance of plants against plant-parasitic nematodes (McSorley 2011). However, urea is readily converting to the toxic ammonia $\left(\mathrm{NH}_{3}\right)$ by the urease enzyme, which is readily present in the soil (Rodriguez-Kabana 1986). The nematicidal properties of ammonia could be attributed to either its plasmolysing effect in the immediate vicinity of its application site in the soil, or the possibility that ammonia could exert a selective influence for microbial antagonists of nematodes, particularly fungi (Rodriguez-Kabana 1986; ChavarriaCarvajal and Rodriguez-Kabana 1998 and SantanaGomes et al. 2013).

Both guava and fig have two fruiting periods a year in Jazan region, southwest of Saudi Arabia (Mars to May and November to January of the second year). In both periods during the present study, all the tested treatments significantly increased $(P \leq 0.05)$ the number of fruits/tree either for guava or fig (Tables 4 and 5). Treatments which included the combinations between fungal and bacterial parasites along with chicken manure had the highest numbers of guava fruits/tree, followed by the treatment with the nematicide carbofuran 10G (Table 4). However, treatments of fungal and bacterial parasites enriched with any of the chicken manure, urea $46 \%$, cow manure, or compost also gave the highest numbers of fig fruits/tree like the nematicide, carbofuran 10G or may be more (Table 5). These findings might be greatly supported with some previous studies, which have repeatedly proved the effectiveness of carbamate and organophosphorus nematicides in controlling plant-parasitic nematodes and increasing the yield of some tropical and subtropical fruit trees in different countries (Queneherve et al. 1991). Similarly, other previous studies also proved the usefulness of some non-chemical treatments such as cow manure and poultry compost in managing the plant parasitic nematodes attacking guava trees and increasing their fruit yields (Souza et al. 2006 and Gomes et al. 2010). Obtained results also obviated that adding each of urea $46 \%$, chicken manure, or cow manure to the tested fungal parasites and the bacteria $P$. penetrans increased the yield of guava and fig trees, and these yield increments were sometimes higher than those of increments gained by the use of carbofuran 10G. These results are consistent with the findings of Rao (2010) who reported that the fungus $P$. lilacinum and the bacteria $P$. fluorescens enriched the farm yard manure fairly controlled the reniform nematode, $R$. reniformis and the root-knot

Table 4 Effect of different combinations of integrated control measures on the number of guava, Psidium guajava, fruits

\begin{tabular}{|c|c|c|}
\hline \multirow[t]{2}{*}{ Treatment } & \multicolumn{2}{|c|}{ Number of fruits/tree } \\
\hline & $\begin{array}{l}\text { 1st yield } \\
\text { Mars-May } 2016\end{array}$ & $\begin{array}{l}\text { 2nd yield } \\
\text { Nov. 2016-Jan. } 2017\end{array}$ \\
\hline P. lilacinum + P. penetrans + chicken manure & $86.75 \mathrm{a}$ & $64.25 \mathrm{a}$ \\
\hline$V \cdot$ chlamydosporium + P. penetrans + chicken manure & $81.00 \mathrm{~b}$ & $45.50 \mathrm{c}$ \\
\hline T. harzianum + P. penetrans + chicken manure & $53.25 d$ & $36.25 d$ \\
\hline$P$. lilacinum $+P$. penetrans + cow manure & $27.50 \mathrm{f}$ & $25.00 \mathrm{gh}$ \\
\hline$V$. chlamydosporium $+P$. penetrans + cow manure & $21.75 \mathrm{ghi}$ & $45.00 \mathrm{c}$ \\
\hline T. harzianum + P. penetrans + cow manure & $22.50 \mathrm{gh}$ & $34.00 \mathrm{e}$ \\
\hline$P$. lilacinum $+P$. penetrans + compost & $23.50 \mathrm{~g}$ & $24.25 \mathrm{hi}$ \\
\hline$V$. chlamydosporium $+P$. penetrans + compost & $20.25 \mathrm{i}$ & $27.25 \mathrm{fg}$ \\
\hline$T$. harzianum $+P$. penetrans + compost & $20.50 \mathrm{i}$ & 35.75 de \\
\hline P. lilacinum + P. penetrans + urea $46 \%$ & $50.25 i$ & $36.75 d$ \\
\hline V. chlamydosporium + P. penetrans + urea $46 \%$ & $44.50 \mathrm{e}$ & $22.00 \mathrm{i}$ \\
\hline T. harzianum + P. penetrans + urea $46 \%$ & 45.75 e & $29.25 f$ \\
\hline Carbofuran 10G & $70.25 \mathrm{c}$ & $52.75 \mathrm{~b}$ \\
\hline Nematode control & $16.75 \mathrm{j}$ & $19.50 \mathrm{j}$ \\
\hline $\mathrm{LSD}_{0.05}$ between treatments & 2.44 & \\
\hline $\mathrm{LSD}_{0.05}$ between time & 2.35 & \\
\hline $\mathrm{LSD}_{0.05}$ between treatments $\times$ time & 8.82 & \\
\hline
\end{tabular}

Data are average of four replicates (trees) each

Values followed by the same letter(s) in a column are not significantly different at $P \leq 0.05$

P. lilacinum $=$ Purpureocillium lilacinum, $P$. penetrans $=$ Pasteuria penetrans, $V$. chlamydosporium $=$ Verticillium chlamydosporium, $T$. harzianum $=$

Trichoderma harzianum 
Table 5 Effect of different combinations of integrated control measures on the number of fig, Ficus carica, fruits

\begin{tabular}{|c|c|c|}
\hline \multirow[t]{2}{*}{ Treatment } & \multicolumn{2}{|c|}{ Number of fruits/tree } \\
\hline & $\begin{array}{l}\text { 1st yield } \\
\text { Mars-May } 2016\end{array}$ & $\begin{array}{l}\text { 2nd yield } \\
\text { Nov. 2016-Jan. } 2017\end{array}$ \\
\hline P. lilacinum + P. penetrans + chicken manure & $38.25 a b c$ & $100.50 \mathrm{bcd}$ \\
\hline V. chlamydosporium + P. penetrans + chicken manure & 32.50 bcde & $97.75 \mathrm{bcd}$ \\
\hline T. harzianum + P. penetrans + chicken manure & 29.50 cde & $95.25 \mathrm{~cd}$ \\
\hline P. lilacinum $+P$. penetrans + cow manure & $27.00 \mathrm{e}$ & 91.75 de \\
\hline$V$. chlamydosporium $+P$. penetrans + cow manure & 31.25 bcde & $81.75 \mathrm{fg}$ \\
\hline T. harzianum + P. penetrans + cow manure & $27.25 \mathrm{e}$ & $63.75 \mathrm{~h}$ \\
\hline$P$. lilacinum $+P$. penetrans + compost & $43.50 \mathrm{a}$ & 82.25 ef \\
\hline$V \cdot$ chlamydosporium $+P$. penetrans + compost & 28.25 de & $128.50 \mathrm{a}$ \\
\hline T. harzianum $+P$. penetrans + compost & 28.75 cde & 84.75 ef \\
\hline P. lilacinum + P. penetrans + urea $46 \%$ & 33.25 bcde & 106.75 b \\
\hline V. chlamydosporium + P. penetrans + urea $46 \%$ & $38.00 \mathrm{abcd}$ & $78.75 \mathrm{~g}$ \\
\hline T. harzianum + P. penetrans + urea $46 \%$ & 36.50 abcde & $98.75 \mathrm{bcd}$ \\
\hline Carbofuran10G & $40.50 \mathrm{ab}$ & $103.25 \mathrm{bc}$ \\
\hline Nematode control & $16.50 \mathrm{f}$ & $35.75 i$ \\
\hline $\mathrm{LSD}_{0.05}$ between treatments & 10.05 & \\
\hline $\mathrm{LSD}_{0.05}$ between time & 3.80 & \\
\hline $\mathrm{LSD}_{0.05}$ between treatments $\times$ time & 14.21 & \\
\hline
\end{tabular}

Data are average of four replicates (trees) each

Values followed by the same letter(s) in a column are not significantly different at $P \leq 0.05$

P. lilacinum $=$ Purpureocillium lilacinum, $P$. penetrans $=$ Pasteuria penetrans, V. chlamydosporium $=$ Verticillium chlamydosporium, $T$. harzianum $=$

Trichoderma harzianum

nematode, $M$. incognita and increased the yield of papaya crop by $26 \%$.

Regression analysis showed a significant negative linear relationship between the number of nematodes $/ \mathrm{kg}$ soil and both the number of guava fruits/tree $(y=-$ $0.03 x+54.54$ ) (Fig. 1) and fig fruits/tree $(y=-0.124 x+$ 112.03) (Fig. 2). It means that, in both relations, the number of fruits/tree gradually decreased as the number of nematodes/kg soil was increased. Similar results were previously obtained by Ibrahim (2002) and Kim and Ferris (2002).

\section{Conclusion}

It is concluded from the present study that carbofuran $10 \mathrm{G}$ was the most effective treatment in suppressing the nematode densities in the rhizosphere of guava and fig trees, followed by the combinations of the fungal (P. lilacinum, T. harzianum, and $V$. chlamydosporium) and

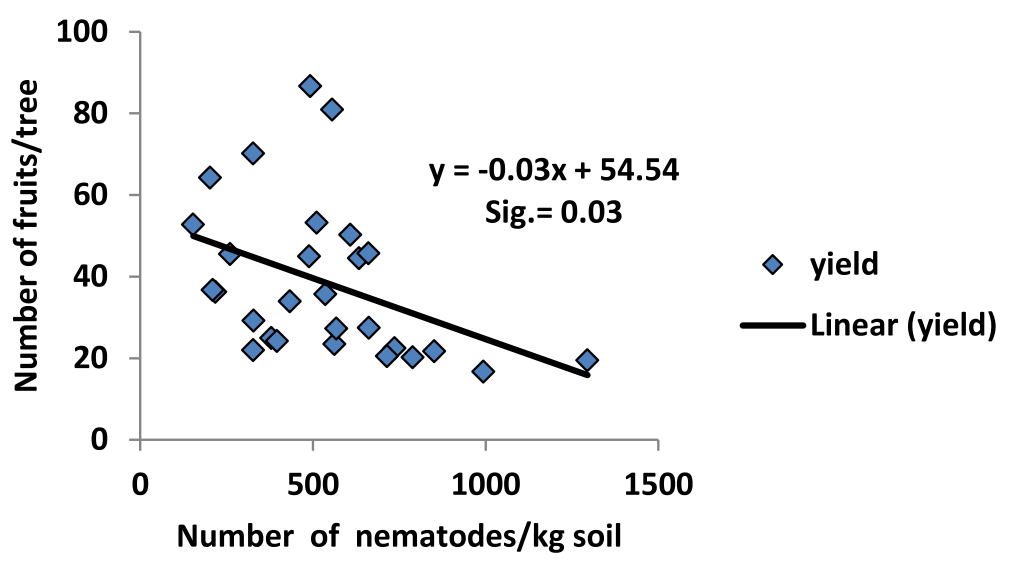

Fig. 1 Relationship between the number of nematodes/kg soil and the number of guava fruits/tree 


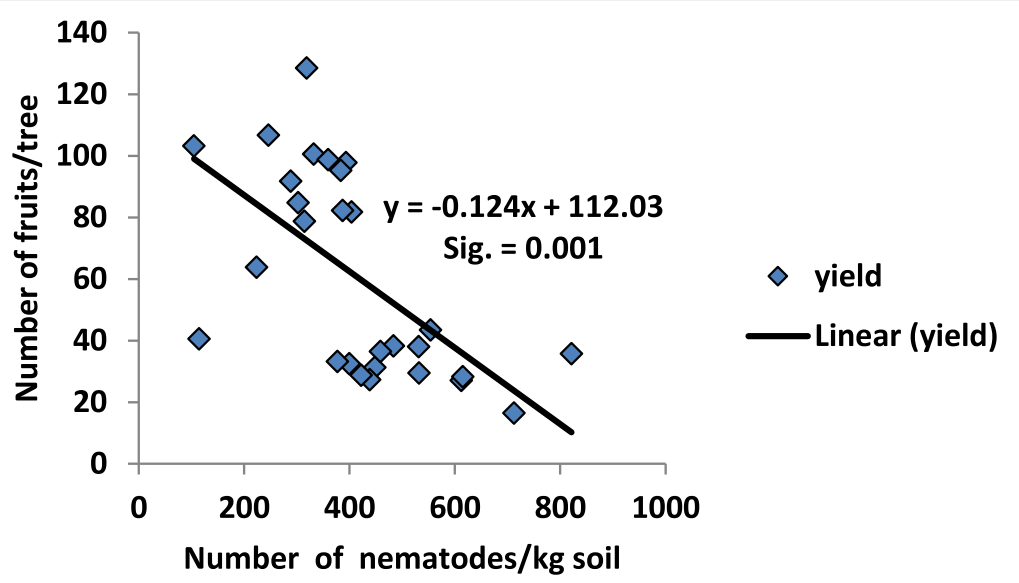

Fig. 2 Relationship between the number of nematodes $/ \mathrm{kg}$ soil and the number of fig fruits/tree

bacterial (P. penetrans) parasites along with chicken and cow manures and urea $46 \%$. However, treatments which included the combinations of fungal and bacterial parasites along with chicken manure gave the highest numbers of guava and fig fruits/tree, followed by carbofuran 10G. The use of such effective bio-control combinations in managing plant-parasitic nematodes in the tropical guava and fig orchards should be encouraged due to the dangerous hazards of chemical nematicides.

\section{Acknowledgements}

The authors are thankful to the General Directorate of Research Grants Programs (Project \# At-35-51), King Abdulaziz City for Science and Technology for the financial support and cooperation in completion of this work.

\section{Funding}

This study was funded by the General Directorate of Research Grants Programs (Project \# At-35-51), King Abdulaziz City for Science and Technology, Riyadh, Saudi Arabia.

\section{Availability of data and materials}

The data sets used and/or analyzed during the current study are available from the corresponding author on reasonable request.

\section{Authors' contributions}

AD participated in the planning and designing the experiments, implementation the experiments, nematode identification, analyzing data, and writing the manuscript. FA participated in the planning and implementation of the experiments, sampling, lab work, and writing the draft. HL participated in the implementation of the experiments, sampling, lab work, and collecting data. All authors read and approved the final manuscript.

\section{Authors' information}

Prof. Ahmed A.M. Dawabah, Professor of plant pathology and nematology, Nematode Diseases Department, Plant Pathology Research Institute, Agricultural Research Center, Giza, Egypt.

Prof. Fahad A. Al-Yahya, Professor of plant pathology and nematology, Plant Protection Department, College of Food and Agricultural Sciences, King Saud University, Riyadh, Saudi Arabia.

Mr. Hamzeh A. Lafi, Lecturer of Plant Protection, Plant Protection Department, College of Food and Agricultural Sciences, King Saud University, Riyadh, Saudi Arabia.
Ethics approval and consent to participate

The study was conducted on nematode species that are abundant in the ecosystem and does not require ethical approval. Approval of participation is ensured by all authors.

Consent for publication

The manuscript has not been published in completely or in part elsewhere.

\section{Competing interests}

The authors declare that they have no competing interests.

\section{Publisher's Note}

Springer Nature remains neutral with regard to jurisdictional claims in published maps and institutional affiliations.

\section{Author details}

${ }^{1}$ Nematode Diseases Research Department, Plant Pathology Research Institute, Agricultural Research Center, 9 Gameat El-Qahera street, Giza 12619, Egypt. ${ }^{2}$ Plant Protection Department, College of Food and Agricultural Sciences, King Saud University, P. O. Box 2460, Riyadh 11451, Saudi Arabia.

Received: 31 January 2019 Accepted: 14 April 2019

Published online: 08 May 2019

\section{References}

Abd-Elgawad MM, El-Mougy NS, El-Gamal NG, Abdel-Kader MM, Mohamed MM

(2010) Protective treatments against soil borne pathogens in citrus orchards. J Plant Prot Res 50:477-484

Akhtar M, Malik A (2000) Roles of organic soil amendments and soil organisms in the biological control of plant-parasitic nematodes: a review. Bioresour Technol 74:35-47

Alam MM (1992) In: Nemtol PJ (ed) Effect of ammonia on the population of plant parasitic nematodes and growth of some vegetables, vol 10, pp 133137

Al-Hazmi AS, Dawabah AAM (2014) Effect of urea and certain NPK fertilizers on the cereal cyst nematode (Heterodera avenae) on wheat. Saudi J Biol Sci 21: 191-196

Al-Hazmi AS, Dawabah AAM, Al-Nadhari SN (2013) Verticillium chlamydosporium, a fungal parasite of the cereal cyst nematode (Heterodera avenae) in the Saudi fields. In: The $4^{\text {th }}$ International Cereal Nematodes Initiative Workshop. 22-24 Aug., 2013. Friendship Hotel, Beijing

Al-Hazmi AS, Dawabah AAM, Al-Nadhari SN, Al-Yahya FA (2017) Comparative efficacy of different approaches to managing Meloidogyne incognita on green bean. Saudi J Biol Sci 24:149-154

Al-Rehiayani S (2007) Suppression of Meloidogyne incognita by soil application of Pasteuria penetrans isolate from Al-Qassim area, Saudi Arabia. Int J Nematol 17:130-136 
Al-Rehiayani S, Motawei MI (2014) Detection and molecular characterization of Pasteuria penetrans isolates parasitizing root-knot nematodes in AL-Qassim area, Saudi Arabia. Biotechnology http://www.omicsgroup.com/conferences/ ACS/conference/pdfs/2113-Poster-Pdf.pdf

Barker K.R. 2013. Opportunities for integrated management of plant-parasitic nematodes in the Near East. http://www.fao.org/docrep/N9978E/v9978e0c.htm

Basha MA (1998) Fruit production in the Kingdom of Saudi Arabia. King Saud Univ. Press, Riyadh, p 642 (In Arabic)

Bird AF, Brisbane G (1988) The influence of Pasteuria penetrans in field soils on the reproduction of root-knot nematodes. Rev de Nématol 11:75-81

Chavarria-Carvajal JA, Rodriguez-Kabana R (1998) Changes in soil enzymatic activity and control of Meloidogyne incognita using four organic amendments. Nematropica 28:7-18

Chen ZX, Dickson DW (1998) Review of Pasteuria penetrans: biology, ecology, and biological control potential. J Nematol 30:313-340

Chen ZX, Dickson DW, McSorley R, Mitchell DJ, Hewlett TE (1996) Suppression of Meloidogyne arenaria race 1 by soil application of endospores of Pasteuria penetrans. J Nematol 28:159-168

Dawabah AAM, Al-Yahya FA (2017) Integrated management of nematode diseases on some tropical fruit trees in Jazan Region, South West Saudi Arabia. Technical report. King Abdul-Aziz City for Science and Technology (KACST), Riyadh, p 118

De Leij AAM, Davis KG, Kerry BR (1992) The use of Verticillium chlamydosporium Goddard and Pasteuria penetrans (Thorne) Sayre \& Starr alone and in combination to control Meloidogyne incognita on tomato plants. Fund Appl Nematol 15:235-242

Gomes VM, Souza RM, Corrêa FM, Dolinski C (2010) Management of Meloidogyne mayaguensis in commercial guava orchards with chemical fertilization and organic amendments. Nematol Brasil 34:23-30

Gomes VM, Souza RM, Silva MM, Dolinski C (2008) Nutritional status of guava (Psidium guajava L.) plants parasitized by Meloidogyne mayaguensis. Nematol. Brasil. 32:154-160

Hewlett TE, Dickson DW (1993) A centrifugation method for attaching endospores of Pasteuria penetrans to nematodes. J Nematol 25:785-788

Ibrahim AAM (2002) Effect of initial population densities of Meloidogyne javanica on tomato growth and nematode reproduction. Alexandria. J Agric Res 47: $181-189$

Jatala P (1986) Biological control of plant parasitic nematodes. Annu Rev Phytopathol 24:453-489

Jindapunnapat K, Chinnasri B, Kwankuae S (2013) Biological control of root-knot nematodes (Meloidogyne enterolobii) in guava by the fungus Trichoderma harzianum. J Dev Sustainable Agric 8:110-118

Kim DG, Ferris H (2002) Relationship between crop losses and initial population densities of Meloidogyne arenaria in winter-grown oriental melon in Korea. Nematol 34:43-49

Le Roux HF, Pretorius MC, Huisman L (2000) Citrus nematode IPM in Southern Africa. Proc Int Soc Citriculture 2:823-827

McSorley R (2011) Overview of organic amendments for management of plantparasitic nematodes, with case studies from Florida. J Nematol 43:69-81

Mokbel AA (2014) Nematodes and their associated host plants cultivated in Jazan province, Southwest Saudi Arabia. Egypt J Exp Biol (Zool) 10:35-39

Oka Y (2010) Mechanisms of nematode suppression by organic soil amendments—a review. Appl Soil Ecol 44:101-115

Queneherve P, Cadet P, Mateille T (1991) New approaches to chemical control of nematodes on bananas: field experiments in the Ivory Coast. Rev de Nematol 14:543-549

Rao MS (2007) Papaya seedlings colonized by the bio-agents Trichoderma harzianum and Pseudomonas fluorescens to control root-knot nematodes. Nematol Medit 35:199-203

Rao MS (2010) Effect of combinations of bio-pesticides on the management of nematodes on Carica papaya L. Acta Hort 1:459-464

Rodriguez-Kabana R (1986) Organic and inorganic nitrogen amendments to soil as nematode suppressants. J Nematol 18:129-135

Sahebani N, Hadavi N (2008) Biological control of the root-knot nematode Meloidogyne javanica by Trichoderma harzianum. Soil Biol Biochem 40:2016-2020

Santana-Gomes SM, Dias-Arieira CR, Roldi M, Dadazio TS, Marini PM, Barizao DAO (2013) Mineral nutrition in the control of nematodes. Afr J Agric Res 8:24132420

Siddiqi IA, Islam S, Khan A, Shaukat SS (2007) The effects of soil organic amendments on three plant-parasitic nematode species and yield of datepalm (Phoenix dactylifera). Sarhad J Agric 23:753-758
Soltani T, Nejad RF, Ahmadi AR, Fayazi F (2013) Chemical control of root-knot nematode (Meloidogyne javanica) on olive in the greenhouse conditions. J Plant Pathol Microbiol 4:183. https://doi.org/10.4172/2157-7471.1000183

Souza RM, Nogueira MS, Lima IM, Melarato M, Dolinski CM (2006) Manejo do Nematóide das galhas da goiabeira em São da Barra (RJ) e relato de novos hospedeiros. Nematol Brasil. 30:165-169

SPSS (2016) SPSS Base 20.0 for windows user's guide. SPSS Inc, Chicago

Sturhan D (1988) New host and geographical records of nematode-parasitic bacteria of the Pasteuria penetrans group. Nematologica 34:350-356

\section{Submit your manuscript to a SpringerOpen ${ }^{\circ}$ journal and benefit from:}

- Convenient online submission

- Rigorous peer review

- Open access: articles freely available online

- High visibility within the field

- Retaining the copyright to your article

Submit your next manuscript at $\boldsymbol{\nabla}$ springeropen.com 